\title{
2 自由度積分型最適サ一ボ系を用いた磁気浮上搬送制御の実現*
}

\author{
小林 義光 ${ }^{* 1}$, 亀山 頌太 ${ }^{* 2}$, 佐々木 実 ${ }^{* 3}$
}

\section{An Active Electromagnetic Levitation Conveyance System by Using Two-Degree-of-Freedom Optimal Servosystems}

\author{
Yoshimitsu KOBAYASHI ${ }^{*}$, Shota KAMEYAMA and Minoru SASAKI \\ ${ }^{* 1}$ Department of Electronic Control Engineering, Gifu National College of Technology \\ 2236-2 Kamimakuwa, Motosu-shi, Gifu, 501-0495, Japan
}

This paper describes an active electromagnetic levitation conveyance system incorporating a two-degree-of-freedom optimal servo controller. The system uses a mobile stage with an active electromagnet. A state observer estimates the horizontal and vertical position of the levitated object from two Hall voltages and the current and input voltage to the electromagnet. The magnetic levitation uses a state-feedback control based on the estimated vertical position. A conveyance controller must give desired movement while damping undesired sway using the estimated horizontal position. In order to realize it, a two-degree-of-freedom controller combining an optimal servo control with an integral compensator for disturbances is applied to the magnetic levitation conveyance system. In addition it is possible to design the optimal servo gain and the integral compensator gain independently. Sway is minimized by a designed velocity input based on the acceleration and deceleration time of the integral multiple of the natural period. The validity of the proposed method is confirmed by simulation and experiment results.

Key Words : Electromagnetic Levitation, Conveyance Control, Two-Degree-of-Freedom Control System, Hall Element, Observer, Two Dimensional Position Estimation

\section{1. は じめ に}

磁気浮上搬送のロバスト安定化や高速化を実現するためは，浮上物体の浮上方向（鉛直方向）と搬送方向（水 平方向）の位置を検出し, 鉛直方向の浮上制御に合わせて, 水平方向の制振制御も実現することが重要であると 考える. 通常, 磁気浮上系の浮上物体の位置検出にはレーザセンサ等の外界センサを利用しているが，磁気浮上 搬送に対してはセンサの配置に問題が生じるため, これらのセンサの代わりに電磁石の電流と電磁石の磁極部に 取り付けられたホール素子の磁束情報から鉛直位置を推定する磁気浮上搬送系が提案されている(1)(2). のホール素子を用いることで，鉛直・水平位置を推定する方法も提案されているが(3)，水平方向の制振制御に適用 した事例はない.

これまで本研究では, 電磁石の入力電圧, 電流および複数のホール電圧值から線形オブザーバを構成すること で，浮上物体の鉛直・水平位置を推定して，状態フィードバック制御による安定浮上とフィードフォワード制御に よる搬送を実現している ${ }^{(4)}$. フィードフォワード制御には, 固有振動数を励起しない加速度パターンを目標軌道と して入力することで，搬送時の摇れを最小限に抑えることができる．しかし，本研究では，例えば非接触支持型 の塗装システムへの応用を考えており, ワークの非接触支持による浮上時や搬送中の塗料の噴射等による外乱に

\footnotetext{
* 原稿受付 2012 年 7 月 29 日

*1 正員, 岐阜工業高等専門学校電子制御工学科（广501-0495 岐阜県本巣市上真桑 2236-2）

*2 北海道大学工学部機械知能工学科（广060-0808 北海道札幌市北区北 8 条西 5 丁目）

*3 正員, 岐皁大学工学部人間情報システム工学科（广501-1193 岐阜県岐阜市柳戸 1-1）

E-mail: kobayashi@gifu-nct.ac.jp
} 
よって発生した搬送方向の摇れに対しては制振ができないことが課題として挙げられた.

そこで本論文では，この課題を解決して磁気浮上搬送のロバスト化を図るため，浮上制御と同様に水平方向の 変位と速度の推定值を用いて最適状態フィードバック制御を施すことで, 浮上物体の搬送方向に対して制振制御 を実現することを検討する。しかし，水平方向の搬送制御に対しては，搬送軌道への追従性と浮上物体の摇れの 制振性の両者を確立することが必要であり，一般的な積分補償を加えた最適サーボ系を用いると，追従性と制振 性のトレードオフが発生するため, 適切な制御系を設計することが難しい.

そこで, この積分型最適サーボ系のトレードオフの問題を解決する方法として，2 自由度積分型最適サーボ系が 提案されている ${ }^{(5)}$. この手法は, 最適制御をベースとして制振性と追従性を両立する制御系である. その他にも制 振性と追従性を考慮した制御系は提案されているが，本論文では，既に浮上制御に対して最適制御を用いている ため, 今後の浮上制御と搬送制御の統合を考慮して, 浮上制御と同様に最適制御をべースとした 2 自由度積分型 最適サーボ系を磁気浮上搬送に適用することを検討する.

具体的には, 最適サーボ系によって制振制御を実現し, 搬送中の外乱やモデル化誤差によって, 目標速度軌道 から外れた場合のみ, 独立に積分補償が動作することによって速度追従性を確保するものである. ただし, 最適 サーボ系は, 定值の目標值に対して定常状態で追従性を補償するもので, 過渡状態の追従性は補償できない. そ こで, 速やかに定常状態に収束するように入力変化を滑らかにして過渡状態の追従性の問題を解決し, そして加 減速時間を固有振動周期の整数倍で生成することで, 搬送によって固有振動数成分を励起させないように目標速 度軌道を生成する ${ }^{(6)}$.

以上より, 本論文では, 水平方向の変位と速度の推定值を用いた 2 自由度積分型最適サーボ系および加減速時 間が固有振動周期の整数倍である目標速度軌道生成の組合せを提案し, 磁気浮上搬送のロバスト化に有効である ことを数值計算と実験により検証する.

\section{2. 実 験 装 置}

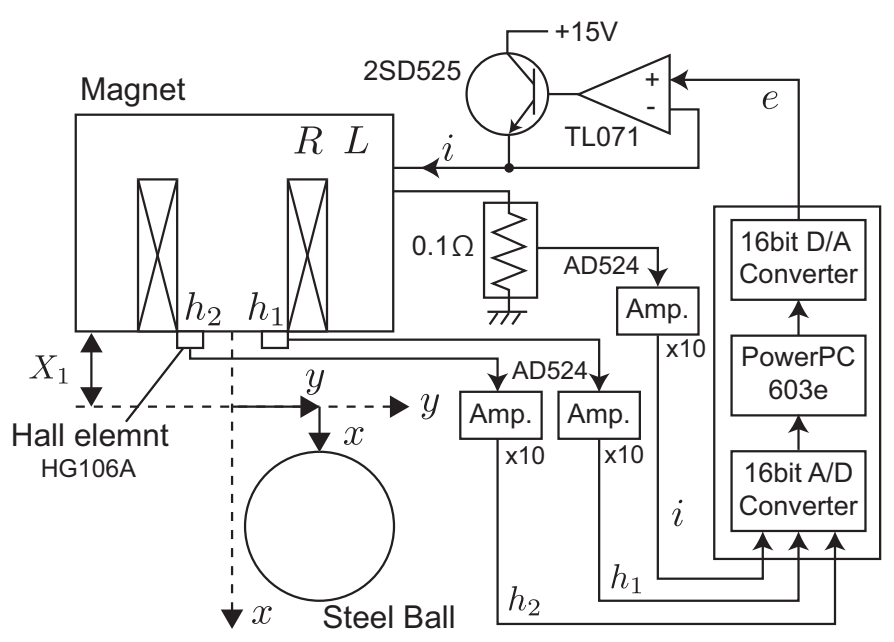

Fig. 1 Experimental setup of magnetic levitation system.

図 1 に実験装置の概略図を示す. 実験装置は, 電磁石（電磁軟鉄 JIS:SUYB2, 直径 70mm, 高さ 60mm, 巻数 $800 \mathrm{~T}$ ），浮上対象物体である鉄球（鋼製，直径 $25 \mathrm{~mm}$, 質量 $68 \mathrm{~g}$ ），ホール素子（旭化成 HG106A），制御ボー ド（dSPACE 社製 DS1104）, 駆動回路, 増幅回路から構成されている. 制御ボードで計算された制御電圧 $e$ は, $\mathrm{D} / \mathrm{A}$ 変換器から駆動回路を経由して電磁石に印加される. 電磁石の電流 $i$ は, 基準抵抗 $0.1[\Omega]$ の電圧をオペアンプ (AD524) で 10 倍に差動増幅して A/D 変換器を用いて制御ボードで計測する.ホール素子は $6 \mathrm{~mm}$ 間隔で 2 個配 置し，左右のホール電圧 $h_{1}, h_{2}$ も同様にオペアンプ（AD524）で 10 倍に差動增幅して制御ボードで計測する. 磁 気浮上モデルは, 浮上物体が鉛直・水平方向を運動するものとし, 定常浮上位置（電磁石から下方 $\left.X_{1}=0.005[\mathrm{~m}]\right)$ からの鋁直位置を $x$, 水平位置を $y$ と寸る. また, $R$ および $L$ は, 電磁石の抵抗およびインダクタンスである.

図 2 に磁気浮上搬送のための搬送装置の概略図を示寸. 搬送機構は AC サーボモータ（安川電機製 SGMJV- 


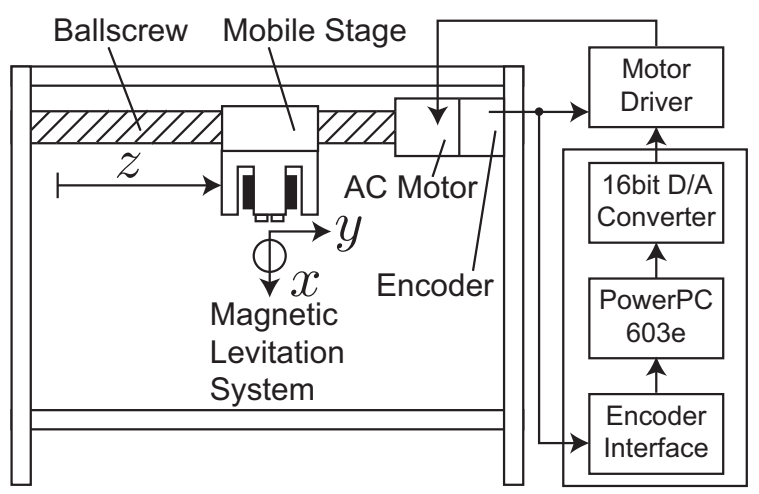

Fig. 2 Experimental setup of conveyance system.

01ADA21）とモータドライバ（安川電機製 SGDV-R90F01A）を用いてボールねじ式スライダ（THK製 SKR3306A0595-1E-1JOH）を駆動する．スライダ部には図 1 の磁気浮上系を取り付け，スライダの移動量 $z$ はエンコーダ值 を制御ボードで計測して算出する。また，ACサーボモータとモータドライバ間では速度制御系が構築されており， 制御ボードのアナログ出力の速度指令で駆動することができる．なお，浮上物体の位置 $x, y$ の実測值は，高速力 メラ（株式会社ライブラリー社製の高速度ギガネット画像入カシステム GA200, VGA モノクロ，解像度 $640 \times 480$ 画素，サンプリング 200[Hz]）をスライダ部に取り付けて撮影し，浮上物体の重心位置を計測することで算出する.

\section{3. 磁気浮上モデルの導出}

図 1 の磁気浮上モデルにおいて $, e=E_{1}+\Delta e, i=I_{1}+\Delta i, x=\Delta x, y=\Delta y, h_{1}=H_{1}+\Delta h_{1}, h_{2}=H_{1}+\Delta h_{2}$ とお き, 定常值 $e=E_{1}, x=0, y=0, i=I_{1}, h_{1}=H_{1}, h_{2}=H_{1}$ からの微小変化 $\Delta e, \Delta i, \Delta x, \Delta y, \Delta h_{1}, \Delta h_{2}$ として定

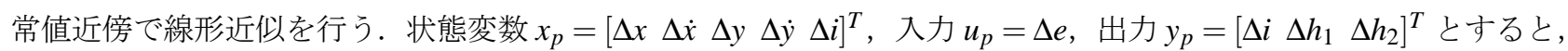
状態方程式は文献 ${ }^{(4)} よ り$ 式(1) で与えられる. また, 表 1 に示す各パラメータは文献 ${ }^{(4)}$ の予備実験の手法によって 決定したものである.

$$
\begin{aligned}
& \dot{x_{p}}=A_{p} x_{p}+B_{p} u_{p}, \quad y_{p}=C_{p} x_{p} \\
& A_{p}=\left[\begin{array}{ccccc}
0 & 1 & 0 & 0 & 0 \\
k_{x} / m & 0 & 0 & 0 & k_{i} / m \\
0 & 0 & 0 & 1 & 0 \\
0 & 0 & -k_{y} / m & 0 & -c_{y} / m \\
0 & k_{v} / L_{1} & 0 & 0 & -R / L_{1}
\end{array}\right], \quad B_{p}=\left[\begin{array}{c}
0 \\
0 \\
0 \\
0 \\
1 / L_{1}
\end{array}\right], \quad C_{p}=\left[\begin{array}{ccccc}
0 & 0 & 0 & 0 & 1 \\
k_{1} & 0 & k_{2} & 0 & k_{3} \\
k_{1} & 0 & -k_{2} & 0 & k_{3}
\end{array}\right], \\
& k_{x}=\frac{2 k I_{1}^{2}}{X^{3}}, \quad k_{i}=-\frac{2 k I_{1}}{X^{2}}, \quad k_{v}=\frac{Q I_{1}}{X^{2}}, \quad X=X_{0}+X_{1}, \\
& k_{1}=-\frac{p\left(a I_{1}+b\right)}{X_{1}^{2}}, \quad k_{2}=a\left(\frac{p}{X_{1}}+r\right), \quad k_{3}=q\left(a I_{1}+b\right) .
\end{aligned}
$$

\section{4. 搬送モデルの導出}

文献 ${ }^{(4)} よ り ，$ 鋁直方向に対しては，式(1)に対してオブザーバを構成し，推定值を用いた状態フィードバック制 御により安定浮上を実現している，そこで，磁気浮上搬送においては，鉛直方向（浮上方向）と水平方向（搬送 
Table 1 System parameters.

\begin{tabular}{c|c|c}
\hline Parameter & Value & Unit \\
\hline \hline$m$ & $63.7 \times 10^{-3}$ & {$[\mathrm{~kg}]$} \\
$g$ & 9.81 & {$\left[\mathrm{~m} / \mathrm{s}^{2}\right]$} \\
$R$ & 4.57 & {$[\Omega]$} \\
$X_{1}$ & $5.00 \times 10^{-3}$ & {$[\mathrm{~m}]$} \\
$I_{1}$ & $7.64 \times 10^{-1}$ & {$[\mathrm{~A}]$} \\
$k$ & $5.53 \times 10^{-5}$ & {$\left[\mathrm{Nm}^{2} / \mathrm{A}^{2}\right]$} \\
$X_{0}$ & $2.20 \times 10^{-3}$ & {$[\mathrm{~m}]$} \\
$Q$ & $8.45 \times 10^{-5}$ & {$[\mathrm{Hm}]$} \\
$L_{1}$ & $1.31 \times 10^{-1}$ & {$[\mathrm{H}]$} \\
$L_{0}$ & $1.19 \times 10^{-1}$ & {$[\mathrm{H}]$} \\
$a$ & 2.17 & {$[\mathrm{~V} / \mathrm{Am}]$} \\
$b$ & $6.99 \times 10^{-2}$ & {$[\mathrm{~V} / \mathrm{m}]$} \\
$p$ & $2.51 \times 10^{-3}$ & {$\left[\mathrm{~m}^{2}\right]$} \\
$q$ & $-3.10 \times 10^{1}$ & {$[-]$} \\
$r$ & $2.58 \times 10^{-1}$ & {$[\mathrm{~m}]$} \\
$H_{1}$ & 1.31 & {$[\mathrm{~V}]$} \\
$k_{x}$ & $1.72 \times 10^{2}$ & {$[\mathrm{~N} / \mathrm{m}]$} \\
$k_{i}$ & -1.63 & {$[\mathrm{~N} / \mathrm{A}]$} \\
$k_{v}$ & 1.25 & {$[\mathrm{Ns} / \mathrm{m}]$} \\
$k_{y}$ & $1.57 \times 10^{1}$ & {$[\mathrm{~N} / \mathrm{m}]$} \\
$c_{y}$ & $7.97 \times 10^{-3}$ & {$[\mathrm{Ns} / \mathrm{m}]$} \\
\hline
\end{tabular}

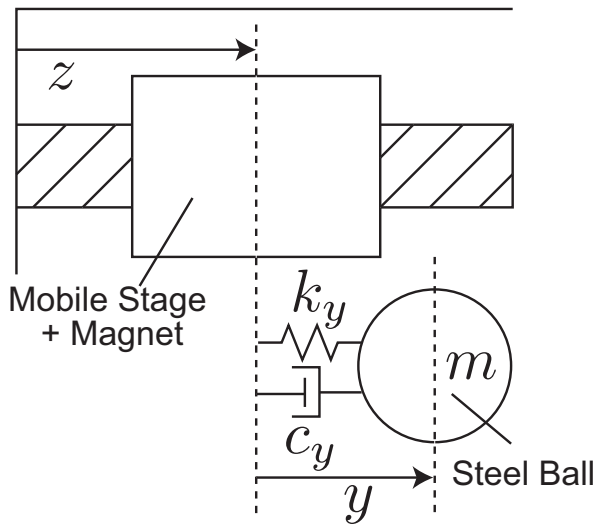

Fig. 3 Model of conveyance system.
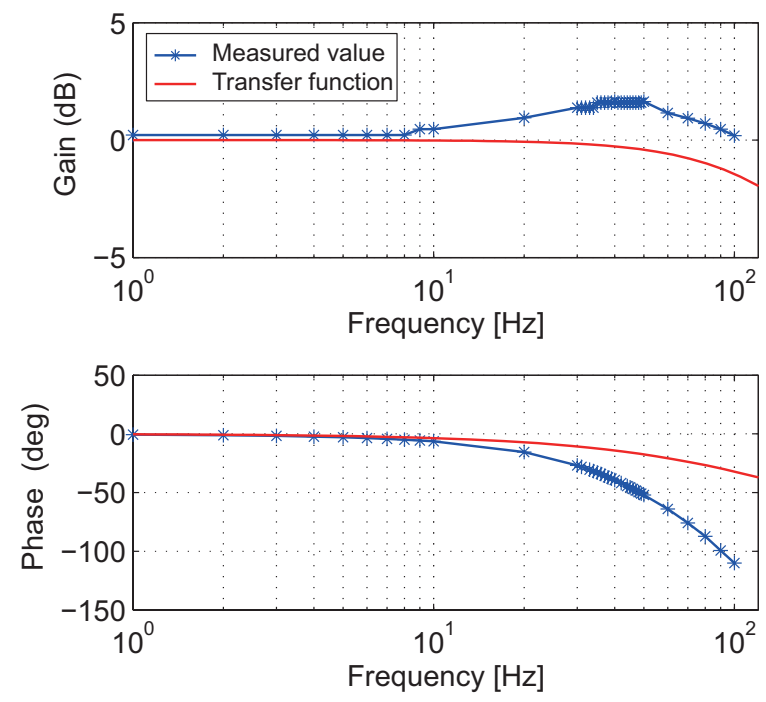

Fig. 4 Bode diagram of mobile stage.

方向）の干渉は考慮せず，今回は水平方向のみの運動を考慮して図 3 の磁気浮上搬送モデルを考える.図 3 から 浮上物体の水平方向の運動方程式はスライダの加速度 $\ddot{z} か ゙$ 作用して次式で与えられる.

$$
m \ddot{y}+c_{y} \dot{y}+k_{y} y=-m \ddot{z}
$$


スライダはモータドライバによって速度制御系が構築されており，速度指令によってスライダを駆動するものとす

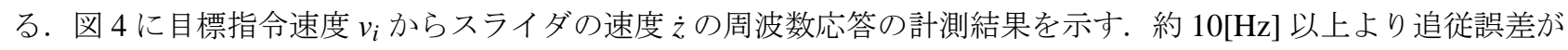
確認できるが，浮上物体の固有振動数 $2.5[\mathrm{~Hz}]$ の 10 倍程度を制御帯域とし，この追従誤差は浮上物体の制振制御 に影響を与えないものと考える，そこで，制御帯域ではスライダは目標速度に追従するものとし，また状態方程 式の表現を考慮して, 次式の一次遅れの伝達関数を仮定する.

$$
\frac{\dot{Z}(s)}{V_{i}(s)}=\frac{1}{T s+1}
$$

ここで, カットオフ周波数 $\omega=1 / T$ は $\omega=1000[\mathrm{rad} / \mathrm{s}]$ を指定し, 実測値との比較のため, 図 4 に式 (3) の周波数応 答を示す. 図 4 より, 実測值と一次遅れの伝達関数に誤差が確認できるが, 制御帯域より高周波領域での誤差で

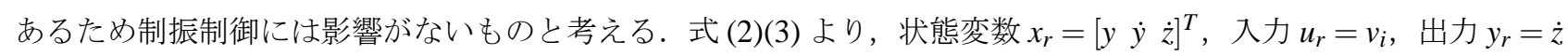
とすると，搬送モデルの状態空間表現は次式で与えられる.

$$
\begin{aligned}
& \dot{x}_{r}=A_{r} x_{r}+B_{r} u_{r}, \quad y_{r}=C_{r} x_{r} \\
& A_{r}=\left[\begin{array}{ccc}
0 & 1 & 0 \\
-k_{y} / m-c_{y} / m & 1 / T \\
0 & 0 & -1 / T
\end{array}\right], B_{r}=\left[\begin{array}{c}
0 \\
-1 / T \\
1 / T
\end{array}\right], C_{r}=\left[\begin{array}{lll}
0 & 0 & 1
\end{array}\right] .
\end{aligned}
$$

ここで, 浮上物体の変位 $y$, 速度 $\dot{y}$ はオブザーバから推定されるため, 状態変数 $x_{r}$ は全て測定可能である.

\section{2 自由度積分型最適サーボ系}

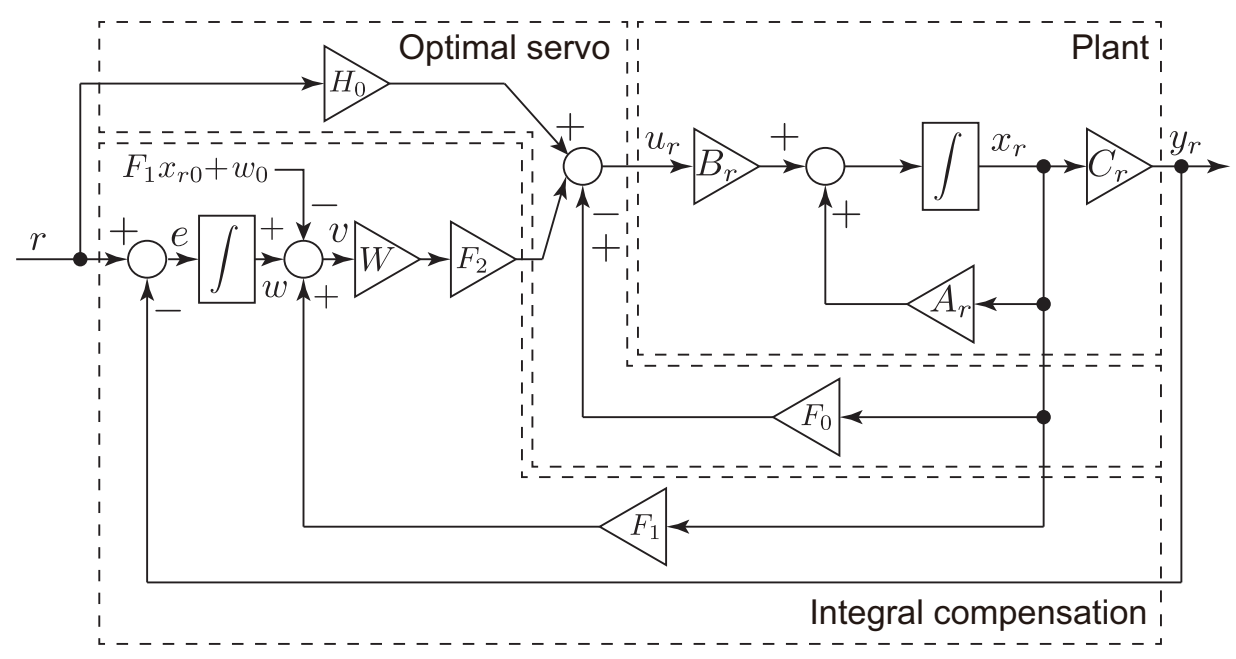

Fig. 5 Two-degree-of-freedom optimal servosystem.

磁気浮上搬送制御系を実現するため, 式 (4) に対して図 5 の 2 自由度積分型最適サーボ系を考える ${ }^{(5)}$. 図 5 の 2 自由度積分型最適サーボ系は, 最適サーボ系と積分補償から構成されており, まず最適サーボ系のゲイン $F_{0}, H_{0}$ から決定する. 式 (4) が目標值 $r$ に収束した場合の状態方程式を次式で示す.

$$
0=A_{r} \bar{x}_{r}+B_{r} \bar{u}_{r}, \quad r=C_{r} \bar{x}_{r}
$$

ここで, 目標值 $r$ に収束した場合の入力を $\bar{u}_{r}$, 状態変数を $\bar{x}_{r}$ とする. そして, 収束前の入力と状態変数の偏差を 
それぞれ $\tilde{u}_{r}=u_{r}-\bar{u}_{r}, \tilde{x}_{r}=x_{r}-\bar{x}_{r}$ とおくと，偏差に対する状態方程式は次式で与えられる.

$$
\dot{\tilde{x}}_{r}=A_{r} \tilde{x}_{r}+B_{r} \tilde{u}_{r}
$$

ここで, 式 (6) に対して最適レギュレータ問題を考え, 次式の評価関数

$$
J_{f}=\int_{0}^{\infty}\left(\tilde{x}_{r}^{T} Q_{f} \tilde{x}_{r}+R_{f} \tilde{u}_{r}^{2}\right) d t
$$

を最小にする最適制御入力を与える状態フィードバック制御則は次式で与えられる.

$$
\tilde{u}_{r}=-R_{f}^{-1} B_{r}^{T} P_{f} \tilde{x}_{r}=-F_{0} \tilde{x}_{r}, \quad F_{0}=R_{f}^{-1} B_{r}^{T} P_{f}
$$

ここで， $F_{0}$ は状態フィードバックゲイン， $P_{f}$ は次式のリカッチ方程式の解である.

$$
A_{r}^{T} P_{f}+P_{f} A_{r}-R_{f}^{-1} P_{f} B_{r} B_{r}^{T} P_{f}+Q_{f}=0
$$

また, $Q_{f}, R_{f}$ はそれぞれ出力, 入力に対する重み行列である. 式(8)より入力 $u_{r}$ については次式で与えられる.

$$
u_{r}=-F_{0} x_{r}+\left(F_{0} \bar{x}_{r}+\bar{u}_{r}\right)
$$

ここで, $F_{0} \bar{x}_{r}+\bar{u}_{r}=\bar{v}$ とおき, $\bar{u}_{r}=-F_{0} \bar{x}_{r}+\bar{v}$ を式に(5) に代入すると次式が得られる.

$$
\bar{v}=-\left[C_{r}\left(A_{r}-B_{r} F_{0}\right)^{-1} B_{r}\right]^{-1} r=H_{0} r, \quad H_{0}=-\left[C_{r}\left(A_{r}-B_{r} F_{0}\right)^{-1} B_{r}\right]^{-1}
$$

ここで, $H_{0}$ はフィードフォワード制御ゲインであり, 式(11)を式(10)に代入すると, 最適サーボ制御則は次式で 与えられる。

$$
u_{r}=-F_{0} x_{r}+H_{0} r
$$

以上より，最適サーボ系は次式で与えられる.

$$
\dot{x_{r}}=\left(A_{r}-B_{r} F_{0}\right) x_{r}+B_{r} H_{0} r, \quad y_{r}=C_{r} x_{r}
$$

式 (13) の最適サーボ系のみでは, 外乱やモデル化誤差に対して, 目標值の追従性が確保できないため, 次に積 分補償のゲイン $F_{1}, F_{2}, W$ を設計する. 最適サーボ系を構築した状態での追従誤差 $e$ は式(13) より次式で与えら れる.

$$
e=r-y_{r}=-C_{r}\left(A_{r}-B_{r} F_{0}\right)^{-1} \dot{x_{r}}
$$

その積分值は次式で表現できる.

$$
w=\int_{0}^{t} e d t+w_{0}=-F_{1} x_{r}+F_{1} x_{r 0}+w_{0}
$$


ここで， $x_{r 0}$ および $w_{0}$ は，それぞれ $x_{r}$ および $w$ の初期值である．また，ゲイン $F_{1}$ は次式で与えられる.

$$
F_{1}=C_{r}\left(A_{r}-B_{r} F_{0}\right)^{-1}
$$

式(15) より，wは状態フィードバックと初期值に依存した定值で打ち消すことができる. そこで, 式(15)の左辺 と右辺の差を $v$ として次式で定義する.

$$
v=w+F_{1} x_{r}-F_{1} x_{r 0}+w_{0}
$$

通常，外乱やモデル誤差が存在しない理想状態では式 (15)(17) より常に $v=0$ が成立するが，外乱やモデル誤差が 存在する場合は $v=0$ は成立しない，そこで，式(17) を用いて，式(12)の最適サーボ制御則に外乱やモデル化誤 差を補償する制御則を追加する。

$$
u_{r}=-F_{0} x_{r}+H_{0} r+F_{2} W\left(w+F_{1} x_{r}-F_{1} x_{r 0}-w_{0}\right)
$$

ゲイン $F_{2}, W$ は積分補償のゲインで後に述べる. 追従誤差の積分值の目標值収束時の定常値との偏差を $\tilde{w}=w-\bar{w}$ とおくと，式(18)の入力の偏差は次式で与えられる.

$$
\tilde{u}_{r}=-F_{0} \tilde{x}_{r}+F_{2} W\left(\tilde{w}+F_{1} \tilde{x}_{r}\right)=\left[\begin{array}{ll}
-F_{0}+F_{2} W F_{1} & F_{2} W
\end{array}\right]\left[\begin{array}{c}
\tilde{x}_{r} \\
\tilde{w}
\end{array}\right]
$$

式(19) は，式(6) と追従誤差督の次式の拡大系の状態フィードバック則と仮定することができる.

$$
\left[\begin{array}{c}
\dot{\tilde{x}}_{r} \\
\dot{\tilde{w}}
\end{array}\right]=\left[\begin{array}{cc}
A_{r} & 0 \\
-C_{r} & 0
\end{array}\right]\left[\begin{array}{c}
\tilde{x}_{r} \\
\tilde{w}
\end{array}\right]+\left[\begin{array}{c}
B_{r} \\
0
\end{array}\right] \tilde{u}_{r}
$$

さらに, ゲイン $F_{2} を$

$$
F_{2}=-R_{f} B_{r}^{T} F_{1}^{T}
$$

とおくと, 式 (19) は拡大系の最適レギュレータ問題の最適制御入力を与える状態フィードバック則として与えら れる。

$$
\tilde{u}_{r}=-R_{f} B_{r}^{T}\left[P_{f}+F_{1}^{T} W F_{1} W F_{1}\right]\left[\begin{array}{c}
\tilde{x}_{r} \\
\tilde{w}
\end{array}\right]
$$

これは, 次式の評価関数

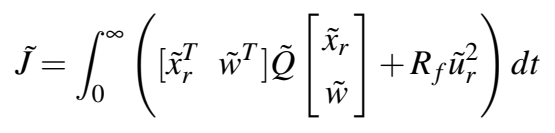

を最小にする最適制御入力を与える状態フィードバック則と等しくなり, 次式の拡大系のリカッチ方程式を満足す るものである. 


$$
\left[\begin{array}{cc}
A_{r}^{T} & -C_{r}^{T} \\
0 & 0
\end{array}\right] \tilde{P}+\tilde{P}\left[\begin{array}{cc}
A_{r} & 0 \\
-C_{r} & 0
\end{array}\right]-R_{f}^{-1} \tilde{P}\left[\begin{array}{c}
B_{r} \\
0
\end{array}\right]\left[\begin{array}{ll}
B_{r}^{T} & 0
\end{array}\right] \tilde{P}+\tilde{Q}=0
$$

ここで， $\tilde{Q}$ は拡大系の評価関数の重み行列， $\tilde{P}$ は次式のリカッチ方程式の解である.

$$
\tilde{P}=\left[\begin{array}{cc}
I & F_{1}^{T} \\
0 & I
\end{array}\right]\left[\begin{array}{cc}
P_{f} & 0 \\
0 & W
\end{array}\right]\left[\begin{array}{cc}
I & 0 \\
F_{1} & I
\end{array}\right]=\left[\begin{array}{ll}
P_{11} & P_{12} \\
P_{12}^{T} & P_{22}
\end{array}\right], P_{11}=P_{f}+F_{1}^{T} W F_{1}, \quad P_{12}=F_{1}^{T} W, P_{22}=W
$$

式 (25) より，式 (22) が最適制御入力を与える状態フィードバック則であることが確認できる。W は正則行列とし て任意に指定することができ，式(18) よりゲイン $W$ は外乱やモデル化誤差に対する積分補償の度合いを調整する もので，最適サーボ系の制振性に影響を与えることなく，独立に設計することができる．また，実際に式 (24)の リカッチ方程式を解く必要はなく，ゲインは $F_{1} ， F_{2}$ は $F_{0}$ から一意に決定されるものである.

ゲイン $F_{0}$ の具体的な設計においては, 浮上物体の変位と速度の推定值にはホール電圧のノイズが大きく影響して いるため, 制振制御を優先して変位と速度の重みを大きくすると，ノイズの影響によってスライダが振動する.そこ で，スライダに対する重みを大きくするように，重多行列を $Q_{f}=\operatorname{diag}\left(5.0 \times 10^{1}, 5.0 \times 10^{1}, 2.0 \times 10^{2}\right), R_{f}=2.0 \times 10^{2}$ に設定してフィードバックゲイン $F_{0}$ を式 $(8)$ より決定した。設計したゲイン $F_{0}$ を用いて， $H_{0}$ は式(11)より， $F_{1}$ は式(16)より， $F_{2}$ は式(21) より決定した．可調整ゲイン $W$ は，大きく設定するほど積分補償が大きく動作して 外乱やモデル化誤差の影響を抑制するが，過大に設定すると制御系が発散する可能性もあるため，数値計算と実 験を繰り返しながら, 最終的に $W=1000$ と決定した.

図 6, 7 に 2 自由度積分型最適サーボ系 $(W=1000)$ と最適サーボ系 $(W=0)$ の閉ループ伝達関数と感度関数の 周波数応答結果を示す．図 6 より，外乱が作用しない場合は，最適サーボ系として動作するため，低周波領域で追 従性が良好であることが確認できます。一方，図 7 より，2 自由度積分型最適サーボ系では，感度関数の低周波領 域が低く抑えられており, 外乱やモデル化誤差が存在した場合に積分補償が動作し, 外乱やモデル化誤差の影響 を抑えて追従性を確保することが確認できる。

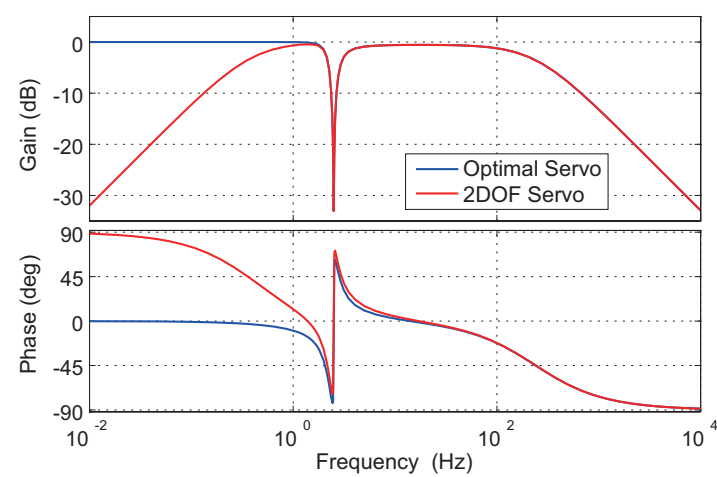

Fig. 6 Bode diagram of closed loop transfer function.

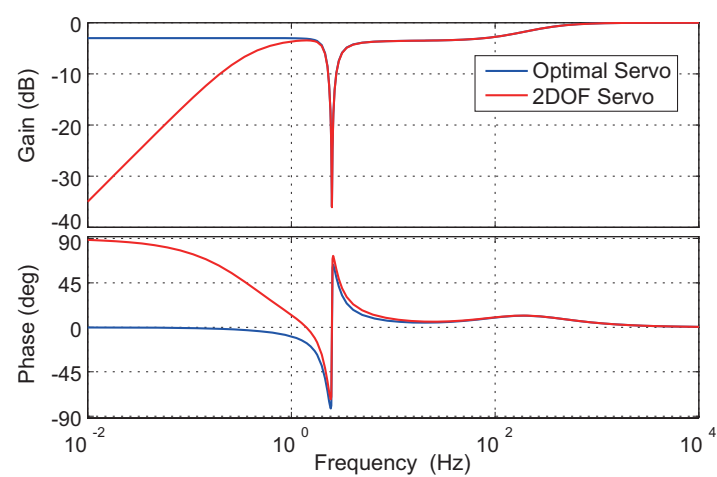

Fig. 7 Bode diagram of sensitivity function.

\section{6. 数 值 計 算}

実機実験では搬送中に同条件で外乱を加えて追従性と制振性を同時に評価することが困難であるため，数值計 算により搬送中の外乱による追従性と制振性を評価する．また，制御対象は式 (4) で表現し，状態変数は全て測定 可能であると仮定する.

図 8，9に $1.5[\mathrm{sec}$ 加搬送を開始し，2.5[sec] 後に 0.05[N] の一定外力を搬送方向側に入力した場合の各制御系 の数值計算の結果を示す. 目標速度軌道は, 文献 $(4)(6)$ より浮上物体の固有振動数を励起することなく, 摇れを最小 限に抑えるためには, 固有振動数周期の整数倍に加速度を連続的に変化させることが有効であることが示されて 
いる．そこで今回は $2[\mathrm{sec}]$ 間で $250[\mathrm{~mm}]$ を移動するものとして, 固有振動数周期 $0.4[\mathrm{sec}]$ の整数倍で連続的に加 減速を行う加速度軌道を図 8,9 のように生成し，その加速度軌道を積分して速度軌道を算出している. 実際には, この速度軌道を目標入力として与えている。

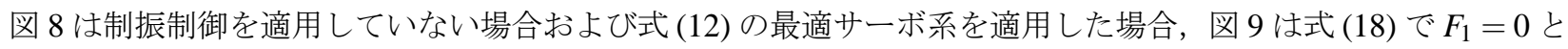
した従来の積分型最適サーボ系を適用した場合および式 (18)の 2 自由度積分型最適サーボ系を適用した場合の搬 送結果を示す. 図 8 より, 制振制御を適用していない場合は搬送によって発生した摇れは速やかに収束している が，外乱が加えられると振動的であることが確認できる. 最適サーボ系は外乱に対しての振動抑制の効果は確認で きるが，外乱に対して追従誤差が残ることが確認できる. 図 9 より，従来の積分型最適サ一ボ系は外乱に対しての 追従性は良好であるが，振動抑制の効果が劣化することが確認できる. 2 自由度積分型最適サーボ系は，振動抑制 の効果を劣化させることなく，若干の追従性誤差は確認できるが，ほぼ追従性が確保できていると判断できる.
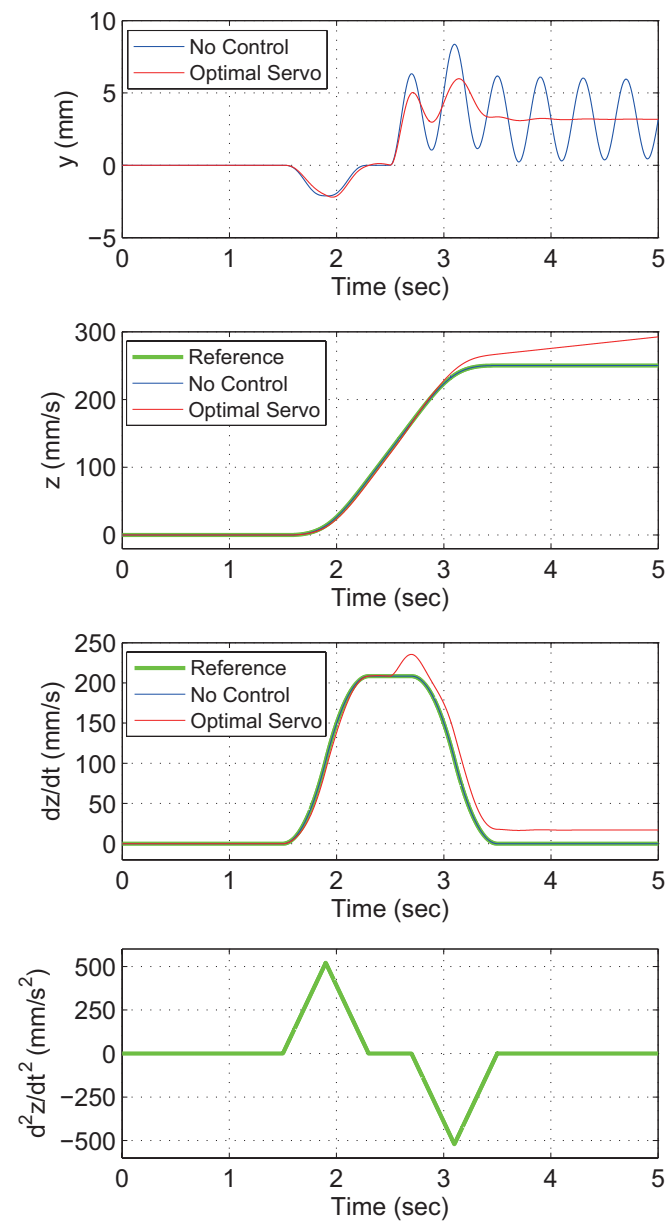

Fig. 8 Simulation results of conveyance control.
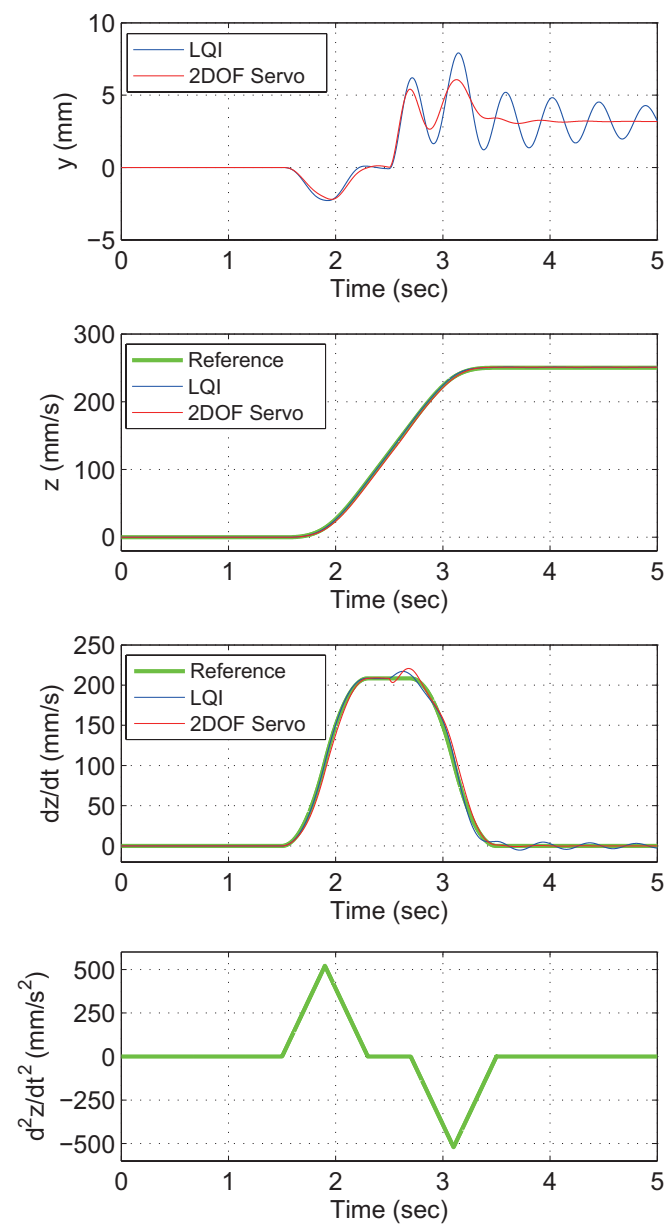

Fig. 9 Simulation results of conveyance control.

\section{7. 実 験 結 果}

実験による検証として，外乱による制振性と搬送制御における追従性の性能評価をそれぞれ評価する。浮上制

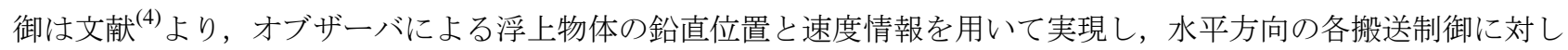
てはオブザーバによる水平方向の変位と速度の推定值を用いて実現する.

図 10〜12 に水平方向にインパルス的な外乱を加えたときの制振制御の実験結果を示す.この実験において，外 乱は人為的に加えているため, 同条件では入力外乱を加えてはいないため, 摇れの最大振幅については比較はでき ない. また, 推定值との比較のため, 浮上物体の変位の実測值はカメラによってを計測する（分解能 $0.23[\mathrm{~mm} /$ 画 
素]）。困 10 は制振制御を適用していない場合, 図 11 は式(12)の最適サーボ系を適用した場合, 図 12 は式 (18) の 2 自由度積分型最適サーボ系の適用した場合の実験結果である. 実測值と推定値はほぼ一致しているが，推定 值にはノイズが大きく影響していることが確認できる. 実験結果の比較より，最適サーボ系と 2 自由度積分型最 適サーボ系により外乱に対する振動抑制の効果が確認できる。また，最適サーボ系は，振動抑制によりスライダ の位置が徐々に移動するが，2 自由度積分型最適サーボ系はスライダが初期位置に戻ることが確認できる。これは 速度の追従誤差の積分值 $w$ を位置誤差として考え，積分值 $w$ をゼロに収束するように制御が働くためであると考 えることができる.
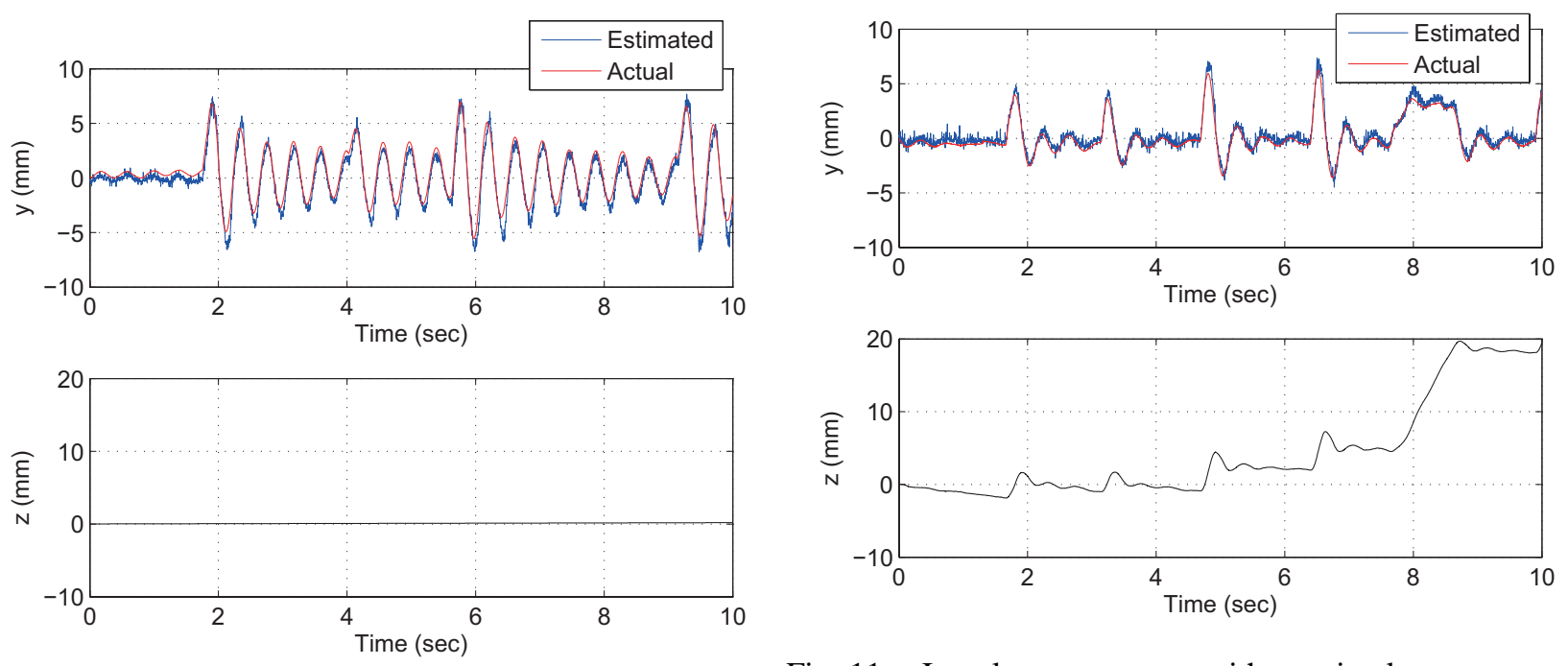

Fig. 10 Impulse response without control.

Fig. 11 Impulse response with optimal servosystem control.

図 13 に各制御系における数值計算と同条件の目標速度軌道を用いた場合の搬送実験の結果を示す. 実験結果よ り，制振制御を適用しない場合は，目標速度に追従して目標地点の $250[\mathrm{~mm}]$ まで到達し，また搬送によって発生 した摇れも速やかに収束していることが確認できる. 最適サーボ系の場合は，ほぼ目標地点に到達していること が確認できるが，搬送開始前の停止中にスライダが移動したため，目標地点で若干の誤差が確認できる.この原 因として，浮上時に初期摇れの制振動作や水平位置の推定誤差の影響でスライダが移動したものと考えることが できる. 2 自由度積分型最適サーボ系では, 数值計算と同様に目標地点まで到達し, 制振制御を適用しない場合と 同程度の摇れであることが確認できる.よって，2 自由度積分型最適サーボ系では，外乱，浮上時の初期摇れおよ び水平位置の推定誤差の影響に対しても追従性を補償することができると考えられる.

\section{8.おわりに}

本研究では磁気浮上搬送制御において，2 自由度積分型最適サーボ系の適用を提案し，以下の結論を得た.

1. 電磁石の入力電圧, 電流および磁極部に配置した 2 個のホール素子のホール電圧の情報からオブザーバによっ て推定した水平方向の変位と速度情報を用いて水平方向の制振制御が実現できることを示した.

2. 2 自由度積分型最適サーボ系を適用した場合，外乱に対しての振動抑制の効果も良好で，外乱，浮上時の初期 摇れおよび水平位置の推定誤差に対しても追従性が劣化しないことを示した.

3. 固有振動数周期の整数倍の目標速度軌道を入力する場合, 搬送によって発生した摇れを最小限に抑えること ができるが，2 自由度積分型最適サーボ系を構成しても同様の摇れで抑制できることを示した.

4. 制振制御の設計において, 振動抑制の速応性を向上させるためには, 変位と速度の推定值に影響を与えてい るホール電圧の計測ノイズの影響を低減させることが課題であることを示した.

5. 2 自由度積分型最適サーボ系は, 定值の目標入力に対して定常状態での収束を補償するため, 目標速度の変化 時においては若干の追従誤差があることを課題として示した. 

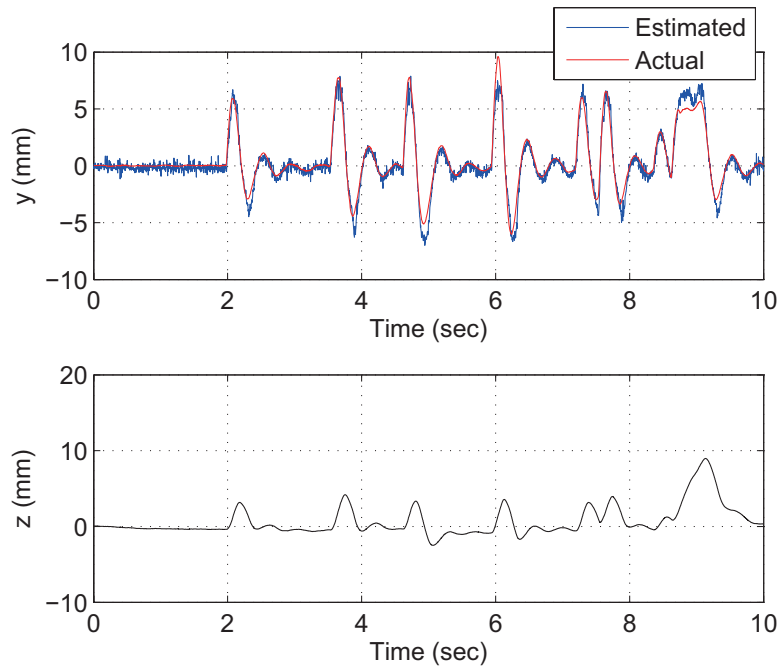

Fig. 12 Impulse response with 2DOF servosystem control.
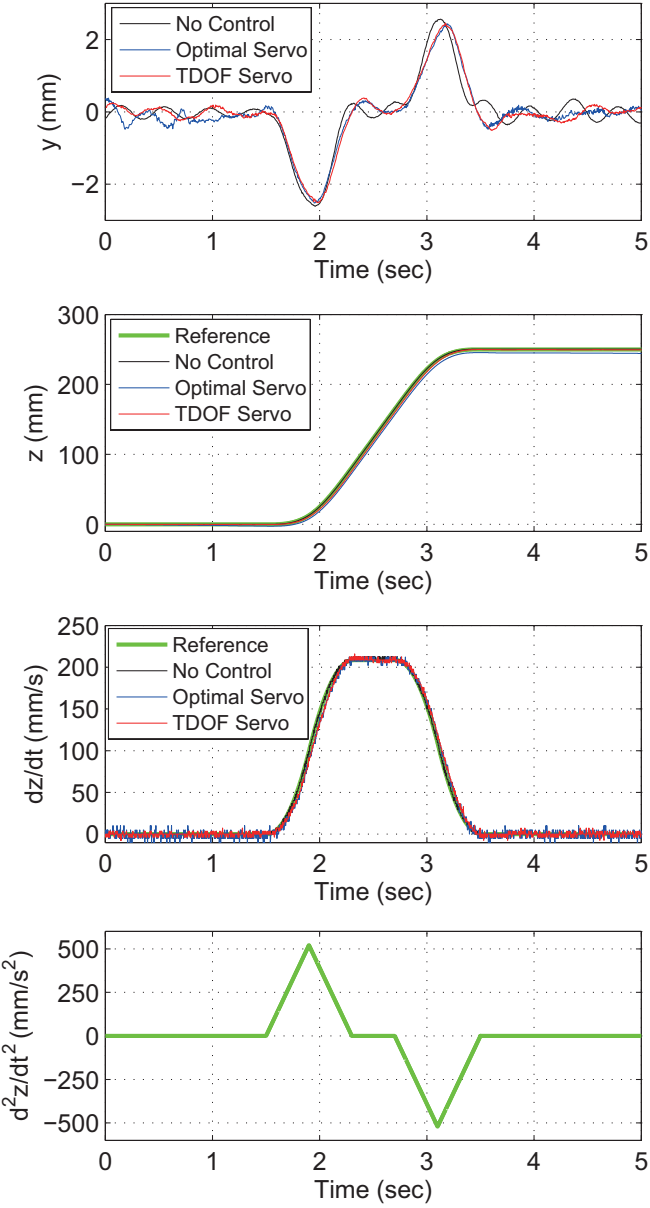

Fig. 13 Experimental results of conveyance control.

謝辞

本研究は, 平成 23 年度 科学研究費助成事業 若手研究 (B)（課題番号:23760396）の研究助成を受けたことを付 記し，関係者各位に感謝申し上げます。

\section{文献}

（1）小島宏行，板垣修，岡部俊和，小林敏雄，“新型ギャップセンサシステムを用いた磁気ロボットハンドにおける球形磁性 体の非接触搬送制御に関する研究”, 日本ロボット学会誌, Vol.14, No.6(1996), pp.886-874.

（2）佐々木実, 小林義光, 堀康郎, “外乱オブザーバを用いた柔軟物体の磁気浮上搬送”, 日本 $A E M$ 学会誌, Vol.10, No.4(2002), pp.413-420.

(3) 井上剛志，平山雅己，小林真子，高木賢太郎，“磁気浮上搬送のためのホール素子を用いた 2 自由度位置推定”，日本機 械学会論文集 C 編, Vol.75, No.760(2009), pp.196-203.

（4）小林義光, 高木健太, 佐々木実, 奥川雅之, “磁気浮上搬送のためのオブザーバによる 2 次元位置推定”, 日本機械学会 論文集 C 編，Vol.76，No.772(2010)，pp.322-329.

(5) 藤崎泰正，池田雅夫，“2 自由度積分型最適サーボ系の構成”，計測自動制御学会論文集，Vol.27, No.8(1991), pp.907-914.

（6）村上新, 池田隆, “加速度入力による天井クレーンの制振位置決め制御”, 日本機械学会 Dynamics and Desigin Conference 2006 CD-ROM 論文集 (2006), 講演番号 128. 